\title{
GAS PLAYS OF THE U.S. GEOLOGICAL SURVEY 1995 NATIONAL ASSESSMENT THAT UNDERLIE REGIONALLY EXTENSIVE SURFACE VOLCANICS
}

by

James W. Schmoker, Thaddeus S. Dyman, Gordon L. Dolton, James E. Fox, Ben E. Law, James A. Peterson, and Marilyn E. Tennyson

Open-File Report 96-099

This report is preliminary and has not been reviewed for conformity with U.S. Geological Survey editorial standards and stratigraphic nomenclature.

U.S. Geological Survey, Mail Stop 960,

Denver Federal Center, Denver, CO 80225 


\section{INTRODUCTION}

Regionally extensive surface volcanic fields degrade the resolution of both geological and geophysical exploration methods, thereby increasing drilling risk by masking the nature of source rocks, reservoirs, traps, and seals. In addition, drilling through thick volcanic sequences is costly relative to drilling in typical sedimentary rocks. For these reasons, gas plays underlying surface volcanic fields might be particularly amenable to research directed toward improving exploration and development technology.

The purpose of this report is to compile and describe geologically based natural-gas plays underlying regionally extensive surface-volcanic areas of the United States. The report thus provides background material for research planning.

The most recent assessment of United States oil and gas resources for which results are documented by data at the play level is the U.S. Geological Survey (USGS) 1995 National Assessment of the onshore United States and adjacent State waters (Gautier and others, 1995; U.S. Geological Survey National Oil and Gas Resource Assessment Team, 1995). As part of the USGS 1995 National Assessment, regional experts (province geologists) were charged with systematically identifying and describing the gas plays of their assessment provinces. For the present study, the identification of gas plays underlying regional volcanic fields is based on documents of the USGS 1995 National Assessment.

Eight plays underlying three thick and extensive surface volcanic fields are identified here (Table 1; Figure 1) and are described in following sections. All of these plays are hypothetical, meaning that none has a discovered accumulation of 6 billion cubic feet of gas (bcfg) or larger. Nevertheless, these plays are based upon established concepts of petroleum geology together with the known geology of an area.

The three volcanic fields and the gas plays underlying them are (Table 1; Figure 1): 1) Miocene Columbia River basalts east of the Cascade Range in Washington and Oregon, underlain by plays 501-503;2) Holocene and Pleistocene Snake River basalts in southern Idaho, underlain by plays 1701-1704; and 3) Eocene Absaroka volcanics in the western Bighorn Basin, Wyoming, underlain by play 3405 .

\section{PLAYS UNDERLYING COLUMBIA RIVER BASALTS EAST OF CASCADE RANGE IN WASHINGTON AND OREGON}

\section{Overview - Eastern Washington Province (5) (modified from Tennyson, 1995)}

The surface of the Eastern Oregon-Washington Province is dominated by the middle to late Miocene Columbia River Basalt Group, a series of basalt flows at least 10,000 ft thick, which erupted from feeders in easternmost Oregon and Washington and adjoining Idaho. This province is bounded on the west by the Cascade Range, on the north by the Canadian border, on the east by the Idaho state line, and on the south by the northern limit of the Great Basin in central Oregon.

Paleogene nonmarine sedimentary and volcanic rocks were deposited extensively across

\footnotetext{
"Province and play numbers are those of the USGS 1995 National Assessment (Gautier and others, 1995).
} 
the region during an episode of regional transtension and diffuse arc volcanism. Thick sequences of Paleocene to Eocene fluvial arkosic sandstone and interbedded mudstone and coal are widespread but discontinuous within the province. In central Washington, for example, Eocene nonmarine arkosic sedimentary rocks exceed $20,000 \mathrm{ft}$ in thickness in the northwest-trending Chiwaukum Graben, whereas such rocks are only locally present and at most a few hundred feet thick in north-central and northeastern Oregon. Exploratory drilling and magnetotelluric surveys have confirmed the presence of 5,000-10,000 ft of nonmarine arkose, mudstone, coal, and volcanic rocks below the Columbia River Basalt Group in central Washington.

The only commercial oil or gas production from the Eastern Oregon-Washington Province was from the small Rattlesnake Hills gas field in southern Washington (Hammer, 1934), which was discovered during the drilling of a water well in 1913. Rattlesnake Hills field was developed in 1930 and produced an estimated $1.3 \mathrm{bcfg}$ (McFarland, 1979) from two vesicular zones in basalt flows sealed by clay interbeds, at depths between 700 and $1,300 \mathrm{ft}$. The gas probably was generated from Eocene coal in the nonmarine sequence below the basalt (Johnson and others, 1993). The field was abandoned in 1941.

During the 1980's, several important test wells demonstrated the presence of thick, lower Tertiary, nonmarine sedimentary sequences beneath basalt in the northwest part of the province (Campbell and Reidel, 1994). Most of these wells had gas shows. Some drill-stem tests were run, but flow rates did not warrant commercial development.

Two conventional gas plays were defined in the USGS 1995 National Assessment in the Eastern Oregon-Washington Province: the Northwestern Columbia Plateau Gas Play (501) and the Central and Northeastern Oregon Paleogene Gas Play (502). One unconventional gas play was defined: the Columbia Basin - Basin-Centered Gas Play (503).

\section{Northwestern Columbia Plateau Gas Play (501) (modified from Tennyson, 1995)}

This play coincides with the inferred extent, beneath the Columbia River Basalt Group, of a sequence of lower Tertiary fluvial and lacustrine sedimentary rocks that is many thousands of feet thick. These source and reservoir rocks were deposited in fault-controlled sub-basins and are interbedded with volcanic and volcaniclastic rocks. The boundaries of this play depend on the inferred presence of sedimentary rocks beneath the basalt and thus are somewhat conjectural.

Potential reservoir rocks consist of Eocene or Oligocene arkosic fluvial sandstones of the Swauk, Chumstick, Roslyn, and Wenatchee Formations, and possibly fractured, vesicular basalt flows of the Columbia River Basalt Group. Porosity of up to 16 percent has been reported in sandstone from three of the wells that penetrated this section (Lingley and Walsh, 1986). Zeolitization is widespread in outcrops of the Chumstick Formation and probably is also present, and reduces permeability, in the subsurface.

Potential source rocks are lacustrine and fluvial shales in the Swauk and Chumstick Formations and possibly coal sequences in the Roslyn Formation. Reported total organic carbon (TOC) values from outcrops are 0-6 wt percent (V. Frizzell, USGS, unpublished data, 1982). Organic matter is mostly type III kerogen. Vitrinite reflectance $\left(\mathrm{R}_{\mathrm{o}}\right)$ values of $0.24-1.38$ percent in exposed rocks indicate that thermal maturity beneath the basalt is probably adequate for gas generation.

Potential traps include large Miocene and younger anticlines and thrust faults (Lingley and Walsh, 1986). Stratigraphic traps are also possible but would be difficult to find. Seals 
might be shale interbeds in the fluvial sequences and basalt flows. Some basalt flows might also function as seals.

Eight deep exploratory wells have been drilled in the play since the 1950's. Several of these were drilled to sub-basalt depths of 6,000-11,000 ft (maximum total depth is 17,518 ft), proving the presence of at least $11,000 \mathrm{ft}$ of sedimentary rocks in part of the area (Lingley and Walsh, 1986). Most of the wells had gas shows. Drill-stem tests in one well yielded 5-6 million cubic feet of gas (mmcfg) per day.

Play 501 is considered to have a high probability of at least a few, and possibly many, small gas accumulations, and a lower probability $(0.60)$ of at least one gas accumulation exceeding $6 \mathrm{bcfg}$. Significant flows of gas were tested in several of the wells that penetrated the basalt, but reservoir strata of adequate quality, thickness, and lateral persistence to contain a conventional gas accumulation larger than a few tens of bcfg have not been demonstrated, despite the possible presence of traps large enough to hold hundreds of bcfg.

\section{Central and Northeastern Oregon Paleogene Gas Play (502) (modified from Tennyson, 1995)}

This play lies south of play 501 (Figure 1) and represents an area where potential reservoir and source-rock units are known or inferred to be coextensive. The boundaries of play 502 are somewhat conjectural, because thick volcanic sequences obscure the distribution of both source and reservoir rocks.

A variety of potential reservoir rocks are present in this play. Outcrop samples of fluvial or deltaic sandstone of the Paleocene or Eocene Herren Formation of Shorey (1976) have average porosity of 12 percent (range 8-21 percent) and average permeability of 8 millidarcies (md) (range 0.4-73 md) (Riddle, 1990). This unit is, at most, about 2,000 ft thick and consists of feldspathic sandstone, carbonaceous shale, and coal, the distributions of which are poorly known. The Herren Formation overlies Mesozoic accreted terranes and underlies the Eocene Clarno Formation. Lithic arkose and volcaniclastic rocks of the Clarno Formation have average porosity of 17 percent (range 4-38 percent) and average permeability of $8 \mathrm{md}$ (Riddle, 1990). Fractured vesicular flows within the Miocene Columbia River Basalt Group are also possible gas reservoirs.

Several potential source rocks are present within play 502. Cretaceous mudstone that crops out near Mitchell, Oregon, contains 0.21 to 3 wt percent TOC (Fisk and Fritts, 1987; Sidle and Richers, 1985). Samples of carbonaceous mudstone and lignitic coal from the Herren Formation contain 0.04-24 wt percent TOC. Samples of the Clarno Formation contain 0.17-4.5 wt percent TOC, and Clarno lignite also has potential as a source of gas (Kuo, 1988). Subsurface samples of the Clarno Formation yield $R_{0}$ values of 0.33 to 0.85 percent (Kuo, 1988), but these values may not represent the deeper portions of the play. A high geothermal gradient is likely in this volcanic province, and a geothermal "event" in early Miocene time might have caused regional maturation (Summer and Verosub, 1992). Asphalt-filled fractures and cavities are reported from numerous localities in central Oregon. Gas occurs in water wells, and gas and oil shows are present in exploratory wells.

Miocene and younger folds and faults may form structural traps. Some folds are large, with wavelengths of several miles. Stratigraphic traps are possible in fluvial rocks of the Herren Formation. Volcanic rocks and shale interbedded with and overlying potential reservoir units are likely seals. Depths of traps could range from a few hundred feet to more than $10,000 \mathrm{ft}$. 
Only about 20 exploratory wells have been drilled in the large play area. An 8,726-ftdeep well on the north flank of the Blue Mountains uplift, drilled in 1957, encountered Clarno Formation volcanics overlying Mesozoic basement. A well more than $9,000 \mathrm{ft}$ deep, drilled in 1989 north of Heppner (Withers and others, 1994), targeted pre-Clarno formations but was abandoned within the Clarno Formation. Several wells in the Ochoco sub-basin drilled between 1955 and 1981 demonstrated the presence of sedimentary rocks beneath the Columbia River basalts but found no commercial hydrocarbon accumulations. Gas shows have been reported in a number of wells, and $4 \mathrm{mmcfg}$ was produced from the Clarno Formation in one well near the town of Clarno (L.H. Fisk, personal communication, 1993). Little exploration activity has occurred in recent years.

Given the large area of play 502 and the number of untested traps, along with widespread seeps and shows, at least a few small accumulations are likely to be present. The possibility of one or more larger accumulations (tens of bcfg) exists, although this possibility is not considered likely because the lateral persistence of adequate reservoir rocks is undemonstrated.

\section{Columbia Basin - Basin-Centered Gas Play (503) (modified from Law, 1995)}

Play 503 is an example of a new category of unconventional, nonassociated-gas plays, termed "continuous" gas plays, defined for the USGS 1995 National Assessment (Schmoker, 1995). The reservoir rock of a continuous gas play is everywhere charged with gas. The entities of the play are not discrete fields, but rather the contiguous gas-charged cells of which the play is composed.

Important characteristics of a continuous gas accumulation that can be recognized in individual wells are abnormal pressure (overpressured or underpressured), thermal maturity at the top of the accumulation between $R_{0}$ of 0.75 and 1.0 percent, and gas as the pressuring phase. Identification of play 503 as an unconventional (continuous) play is based in large part upon these criteria (Law and others, 1994).

Play 503 underlies the widespread Miocene Columbia River Basalt Group in eastern Washington. Its boundaries coincide with those of play 501 (Figure 1). The continuous (unconventional) gas accumulation of play 503 is below and perhaps lateral to the proposed discrete, conventional gas accumulations of play 501.

Throughout most of the play area, subvolcanic rocks consist of lower Tertiary fluvial and lacustrine strata of highly variable thickness. Subsurface data from five widely spaced wells suggest the presence of a continuous, basin-centered gas accumulation within these lower Tertiary strata. The well data show that an overpressured interval begins at depths ranging from 9,500 to $12,700 \mathrm{ft}$ and is at least $6,400 \mathrm{ft}$ thick. Within this overpressured interval, gas has been recovered on drill-stem tests, with little or no produced water. The spatial dimensions of the proposed continuous gas accumulation are imprecisely known, because of insufficient deep drilling and uncertainties as to the geometry of pre-volcanic sub-basins.

Potential reservoir rocks consist of Eocene arkosic fluvial sandstones. The quality of these reservoirs is uncertain. Diagenesis of volcanic material has probably reduced permeabilities. Porosity values ranging from 6 to 15 percent have been calculated from well logs (Lingley and Walsh, 1986).

Source rocks are assumed to be interbedded coals and carbonaceous lacustrine and fluvial shales. Source-rock studies in Washington and Oregon indicate that nearly all organic matter in the region is type III (gas prone) kerogen. The level of thermal maturity is sufficiently high to 
generate gas. The proposed continuous gas accumulation occupies a basin-center position, downdip from water-bearing strata, and does not depend on conventional structural or stratigraphic traps for its existence.

What little exploration activity has taken place in the play area has focused on conventional structural plays. Play 503 is immaturely explored in the context of a continuous, basin-centered gas accumulation. Five wells appear to have penetrated a continuous gas accumulation and several production tests have been made. These tests flowed gas at initial rates as high as $3.1 \mathrm{mmcfg}$ per day. The large thickness and areal extent of the proposed continuous (unconventional) gas accumulation in play 503 result in a large estimate by the USGS (Gautier and others, 1995) for potential additions to technically recoverable resources (Table 1).

\section{PLAYS UNDERLYING SNAKE RIVER BASALTS IN SOUTHERN IDAHO}

\section{Overview - Idaho-Snake River Downwarp Province (17) (modified from Peterson, 1995)}

The southern part of the Idaho-Snake River Downwarp Province includes the late Tertiary Snake River Downwarp. The Snake River Downwarp is an arcuate structural graben about 350 $\mathrm{mi}$ long and 50-100 mi wide extending across southern Idaho from southeastern Oregon to Yellowstone National Park. Initial rifting may have begun in late Miocene time (Warner, 1977). The surface of the Snake River Downwarp (the Snake River Plain) is dominated by basalts of Pleistocene and Holocene age (Malde and Powers, 1962; Armstrong and others, 1975). Relatively recent volcanic activity might locally have provided sufficient heat to generate thermogenic gas from potential source rocks that regionally are thermally immature.

Prior to development of the Snake River Downwarp, the area of southwestern Idaho was occupied by a basin in which sediments of early Tertiary age were probably deposited (Warner, 1980). By early Miocene time, this basin was occupied by a large lake (Lake Bruneau of Miller and Smith, 1967) in which 5,000-7,000 ft of primarily lacustrine sediments of the Miocene Sucker Creek Formation were deposited (Woods, 1994). The Sucker Creek Formation consists of lignitic shale, clay, sandstone, diatomite, volcanic ash and tuff, oolitic and algal limestone, and some lava flows.

Rifting and graben development in Pliocene time initiated development of the modern Snake River Downwarp. A lake formed in the downwarp (Lake Idaho) in which as much as $9,000 \mathrm{ft}$ of Pliocene-Pleistocene fluvial and lacustrine sediments of the Poison Creek, Chalk Hills, and Glenn's Ferry Formations were deposited.

To address the hydrocarbon potential under the basalts of the Snake River Downwarp, four conventional plays updating earlier work by Peterson (1987) were defined in the USGS 1995 National Assessment (Table 1; figure 1): Miocene Lacustrine (Lake Bruneau) Play (1701), Pliocene Lacustrine (Lake Idaho) Play (1702), Pre-Miocene Play (1703), and Older Tertiary Play (1704). 


\section{Miocene Lacustrine (Lake Bruneau) Play (1701) \\ (modified from Peterson, 1995)}

This play is based on the presence of thick, primarily lacustrine sediments of the Sucker Creek Formation, in the southwestern half of the Snake River Downwarp. Potential reservoir rocks are lacustrine and perhaps fluvial sandstones and oolitic or algal carbonates.

Potential source rocks are organic-rich lacustrine shales and lignitic shales or coals of Miocene age. Biogenic gas may have been generated soon after burial. Increased heat flow in the Pliocene associated with crustal extension, coupled with burial under the sediments of Lake Idaho, probably raised temperatures of some source rocks high enough for thermal hydrocarbon generation.

Potential traps are considered to be fault blocks, folds, and stratigraphically isolated sandstone or carbonate units, sealed by shaley beds. Drilling depths range from $5,000 \mathrm{ft}$ to as much as $20,000 \mathrm{ft}$ in the southwestern part of the play, but are shallower on the north flank of the play near the northern edge of the downwarp.

Play 1701 is considered to be a high risk, gas-prone play. Numerous gas and some oil shows have been reported in lacustrine beds of the Sucker Creek Formation, in both shallow water wells and wells drilled for petroleum (Warner, 1977, 1980). Temperature gradients are high in much of the area, and reservoir quality may be adversely affected by diagenesis of intermixed volcanic material.

\section{Pliocene Lacustrine (Lake Idaho) Play (1702) (modified from Peterson, 1995)}

This play is based on the presence of thick, fluvial and lacustrine claystone, sandstone, conglomerate, algal and oolitic limestone, and volcanic ash and tuff, of primarily Pliocene age, in the southwestern half of the Snake River Downwarp. Potential reservoir rocks are fluvial and lacustrine sandstones and conglomerates, and oolitic or algal carbonates.

Potential source rocks are organic-rich lacustrine shales and lignitic shales or coals of Pliocene age. Source rocks in much of the play have not been deeply buried and these are likely to have generated more biogenic gas than thermogenic gas.

Potential traps are considered to be fault blocks, folds, and stratigraphically isolated sandstone or carbonate units, sealed by shaley beds. Drilling depths range from very shallow on the north flank of the play near the edge of the downwarp to $10,000 \mathrm{ft}$ or more in the southwestern part of the play.

Play 1702 is considered to be gas prone (primarily biogenic gas) and of very high risk. Because of its low play probability $(0.10)$, this play was not quantitatively assessed in the USGS 1995 National Assessment.

\section{Pre-Miocene Play (1703) \\ (modified from Peterson, 1995)}

This play is based on the possible presence of Paleozoic and Mesozoic rocks in Laramide thrusts beneath the northeastern half of the Snake River Downwarp. Potential reservoir rocks are marine carbonates and sandstones, which might be highly fractured and are possibly metamorphosed (Peterson, 1987).

Potential source rocks are shales or shaley carbonates of Mississippian, Pennsylvanian, Permian, Triassic, and Jurassic age, which have probably reached a mature or overmature stage of hydrocarbon generation. Traps of Late Paleozoic or Mesozoic age which might have held 
hydrocarbons at some time in the past have probably been destroyed by subsequent tectonic activity. However, more recent traps could be preserved and sealed by impermeable Miocene or Pliocene beds.

Play 1703 is considered to be gas prone and of very high risk. The play would require an unusual combination of structural and stratigraphic factors for a hydrocarbon accumulation of minimum size ( $6 \mathrm{bcfg}$ ) to be present. Because of its low play probability $(0.07)$, this play was not quantitatively assessed in the USGS 1995 National Assessment.

\section{Older Tertiary Play (1704) \\ (modified from Peterson, 1995)}

This play is based on the probable presence of a thick section of early Tertiary rocks (potentially partly marine) in the southwestern corner of the Snake River Downwarp. Regional projections suggest that such rocks are likely to be present in the subsurface, but their presence has not been confirmed by drilling. Potential reservoir rocks are fluvial, lacustrine, and possibly marine sandstones and carbonates of early Tertiary age.

Potential source rocks are organic-rich shales, and lagoonal and coaly beds. Source rocks of the early Tertiary section would be buried under the thick, younger Tertiary rocks of plays 1701 and 1702 and probably would have reached a mature or overmature stage of hydrocarbon generation.

Play 1704 is considered to be deep, gas prone, and of very high risk. Quantitative data are sparse to absent. Because of its low play probability $(0.06)$, this play was not quantitatively assessed in the USGS 1995 National Assessment.

\section{PLAY UNDERLYING ABSAROKA VOLCANICS IN WESTERN BIGHORN BASIN, WYOMING}

\section{Overview - Bighorn Basin Province (34) \\ (modified from Fox and Dolton, 1995)}

The Bighorn Basin is an asymmetric intermontane basin of the Rocky Mountain foreland, located in north-central Wyoming and south-central Montana. Province boundaries are defined by fault-bounded Laramide uplifts that surround the basin. The surface of the western margin of the Bighorn Basin Province, west of Cody, Wyoming (Figure 1), is dominated by Eocene-age volcanic rocks of the Absaroka Volcanic Plateau (Sundell, 1990).

The Bighorn Basin Province is about $175 \mathrm{mi}$ long and $100 \mathrm{mi}$ wide, encompassing an area of 13,200 sq mi. Approximately 2.7 billion barrels of oil and 1,800 bcfg have been discovered (as of year-end 1990) within the province. The majority of production has been from basin-margin anticlinal structures.

The province tends to be oil prone, and the few fields discovered beneath the Absaroka volcanics to date (along the eastern margin of the volcanics) have been oil fields. To address the hydrocarbon potential under the Absaroka volcanics of the western Bighorn Basin Province, one conventional play was defined in the USGS 1995 National Assessment: the Sub-Absaroka Play (3405). Although play 3405 was assessed by the USGS as an oil play, it is included in the present compilation because limited data leave open the possibility of undiscovered nonassociated gas fields. 
References relevant to the following discussion include: Bailey and Sundell (1986), Brittenham and Tadewald (1985), Hagen and Surdam (1984), Stone (1985), Sundell (1983, 1990), and Thomas (1965).

\section{Sub-Absaroka Play (3405) \\ (modified from Fox and Dolton, 1995)}

This play is based on the presence of hydrocarbon-productive Paleozoic and Mesozoic rocks of the Bighorn Basin beneath Eocene-age volcanic rocks of the Absaroka Volcanic Plateau. The limits of the play to the north, east, and south coincide with the extent of the Absaroka volcanics. To the west, the play boundary approximates the position of subcropping sedimentary strata, and is near the eastern boundary of Yellowstone National Park.

Based on nearby production from structural traps, quartzose sandstone of the Pennsylvanian Tensleep Sandstone is a primary reservoir objective. Other potential reservoir rocks include carbonates of the Mississippian Madison Limestone, Permian Phosphoria and Dinwoody Formations, and sandstones of the Pennsylvanian Darwin, Triassic Chugwater, and Jurassic Curtis Formations. At relatively shallow depths, porosity of the Tensleep Sandstone might be as high as 20 percent. Porosity of Madison, Phosphoria, and Dinwoody reservoirs is anticipated to be in the range of 6-12 percent.

Organic-rich source rocks are present in Paleozoic and Mesozoic formations within the Bighorn Basin. The eastern side of play 3405 is only about $25 \mathrm{mi}$ west of the basin axis, so that some source rocks underlying or downdip from the play are buried deeply enough to generate hydrocarbons. Oil seeps are numerous along fractures in the overlying volcanics.

Potential traps are considered to be Laramide domes and plunging anticlines, which in many cases were faulted and eroded prior to being covered by volcanics. Structures in the eastern part of the play are on trend with producing structures of the Bighorn Basin, which may serve as structural analogs for the play. Impermeable beds within these structures form seals. Fields may have multiple pay zones. Depths of objective intervals probably range between 1,000 and 10,000 ft but are difficult to predict, in part because of the rugged topography of the Absaroka Volcanic Plateau.

Play 3405 has not been extensively explored. However, six small oil fields -- Aspen Creek, Baird Peak, Dickie, Prospect Creek, Prospect Creek South, and Skelton Dome -- have been found beneath (but near the eastern edge of) the volcanics. The potential for significant new-field discoveries is considered to be good, but uncertainty exists as to whether geologic conditions might support nonassociated gas fields.

\section{SUMMARY AND DISCUSSION}

The purpose of this report is to compile and describe geologically based natural-gas plays underlying regionally extensive surface-volcanic areas of the United States. The identification of such plays is based on documents of the USGS 1995 National Assessment (Gautier and others, 1995).

Eight plays underlying three surface volcanic fields (Table 1; Figure 1) are identified and described here. All are hypothetical plays for gas, meaning that they have no discovered accumulations of $6 \mathrm{bcfg}$ or larger.

The lack of discovered accumulations that exceed $6 \mathrm{bcfg}$ in these eight plays is considered by the authors to be due in large part to the physical and economic difficulties of exploring beneath thick surface-volcanic sequences. The geologic potential for significant 
accumulations in at least some of these plays appears to be good. The plays discussed here remain frontier areas in terms of exploration maturity, as little known and drilled as some of the World's least explored basins.

\section{REFERENCES CITED}

Armstrong, R.L., Leeman, W.P., and Malde, H.E., 1975, K-Ar dating, Quaternary and Neogene volcanic rocks of the Snake River Plain, Idaho: American Journal of Science, v. 275, p. 225-251.

Bailey, M.H., and Sundell, K.A., 1986, Preliminary results of wildcat drilling in Absaroka volcanic rocks, Hot Springs County, Wyoming [abs]: The Outcrop, Rocky Mountain Association of Geologists, v. 35, p. 3-4.

Brittenham, M.D., and Tadewald, B.H., 1985, Detachment and basement involved structures beneath the Absaroka Range volcanics, in Gries, R.R., and Dyer, R.C., eds., Seismic exploration of the Rocky Mountain Region: Rocky Mountain Association of Geologists and Denver Geophysical Society, p. 31-43.

Campbell, N.P., and Reidel, S.P., 1994, Further exploration for gas warranted in Columbia Basin: Oil and Gas Journal, v. 92, no. 18 (May 2), p. 127-132.

Fisk, L.H., and Fritts, S.G., 1987, Field guide and road log to the geology and petroleum potential of north-central Oregon: Northwest Geology, v. 16, p. 105-125.

Fox, J.E., and Dolton, G.L., 1995, Bighorn Basin Province (034), in Gautier, D.L., Dolton, G.L., Takahashi, K.I., and Varnes, K.L., eds., 1995 National Assessment of United States oil and gas resources -- Results, methodology, and supporting data: U.S. Geological Survey Digital Data Series DDS-30 [CD-ROM].

Gautier, D.L., Dolton, G.L., Takahashi, K.I., and Varnes, K.L., eds., 1995, 1995 National Assessment of United States oil and gas resources -- Results, methodology, and supporting data: U.S. Geological Survey Digital Data Series DDS-30 [CD-ROM].

Hagen, E.S., and Surdam, R.C., 1984, Maturation history and thermal evolution of Cretaceous source rocks of the Bighorn Basin, Wyoming and Montana, in Woodward, Jane, Meissner, F.F., and Clayton, J.L., eds., Hydrocarbon source rocks of the greater Rocky Mountain region: Rocky Mountain Association of Geologists, p. 321-338.

Hammer, A.A., 1934, Rattlesnake Hills gas field, Benton County, Washington: American Association of Petroleum Geologists Bulletin, v. 18, p. 847-859.

Johnson, V.G., Graham, D.L., and Reidel, S.P., 1993, Methane in Columbia River Basalt aquifers: Isotopic and geohydrologic evidence for a deep coalbed gas source in the Columbia Basin, Washington: American Association of Petroleum Geologists Bulletin, v. 77, p. 1192-1207.

Kuo, Lung-Chuan, 1988, Source rock analysis of cuttings from Steele Energy Keys No. 28, Wheeler County, Oregon: Conoco, Inc., Research and Development Department, Exploration Research and Services Division Technical Service Report 9151-G04-1-88, $33 \mathrm{p}$.

Law, B.E., 1995, Unconventional play, in Tennyson, M.E., Eastern Oregon - Washington Province (005), in Gautier, D.L., Dolton, G.L., Takahashi, K.I., and Varnes, K.L., eds., 1995 National Assessment of United States oil and gas resources -- Results, methodology, and supporting data: U.S. Geological Survey Digital Data Series DDS-30 [CD-ROM]. 
Law, B.E., Tennyson, M.E., and Johnson, S.Y., 1994, Basin-centered gas accumulations in the Pacific Northwest--A potentially large source of energy [abs.]: American Association of Petroleum Geologists Annual Meeting, Denver, Colorado, June 12-15, 1994.

Lingley, W.S., Jr., and Walsh, T.J., 1986, Issues relating to petroleum drilling near the proposed high-level nuclear waste repository at Hanford: Washington Geologic Newsletter, v. 14, no. 3, p. 10-19.

Malde, H.E., and Powers, H.A., 1962, Upper Cenozoic stratigraphy of western Snake River Plain, Idaho: Geological Society of America Bulletin, v. 73, p. 1197-1220.

McFarland, C., 1979, History of oil and gas exploration in the State of Washington: Washington Geologic Newsletter, v. 7, no. 3, p. 1-6.

Miller, R.M., and Smith, G.R., 1967, New fossil fishes from Plio-Pleistocene Lake Idaho: University of Michigan Occasional Papers of the Museum of Zoology, v. 654, p. 1-24.

Peterson, J.A., 1987, Pre-thrusting regional stratigraphy and paleotectonics, northern Rocky Mountains and adjacent Cordilleran shelf, U.S., in Miller, W.R., ed., The thrust belt revisited: Wyoming Geological Association, 38th Annual Field Conference, p. 17-26.

Peterson, J.A., 1988, Eastern Great Basin and Snake River Downwarp, geology and petroleum resources: U.S. Geological Survey Open-File Report 88-450-H, 57 p.

Peterson, J.A., 1995, Idaho - Snake River Downwarp Province (017), in Gautier, D.L., Dolton, G.L., Takahashi, K.I., and Varnes, K.L., eds., 1995 National Assessment of United States oil and gas resources -- Results, methodology, and supporting data: U.S. Geological Survey Digital Data Series DDS-30 [CD-ROM].

Riddle, A.J., 1990, Potential petroleum reservoir rocks of north-central Oregon: Loma Linda, California, Loma Linda University, M.S. thesis, $240 \mathrm{p}$.

Schmoker, J.W., 1995, Method for assessing continuous-type (unconventional) hydrocarbon accumulations, in Gautier, D.L., Dolton, G.L., Takahashi, K.I., and Varnes, K.L., eds., 1995 National Assessment of United States oil and gas resources -- Results, methodology, and supporting data: U.S. Geological Survey Digital Data Series DDS-30 [CD-ROM].

Shorey, E.F., 1976, Geology of part of southern Morrow County, northeastern Oregon: Corvallis, Oregon, Oregon State University, M.S. thesis, 131 p.

Sidle, W.C., and Richers, D.M., 1985, Geochemical reconnaissance of Cretaceous inliers in north-central Oregon: American Association of Petroleum Geologists Bulletin, v. 69, p. $412-421$.

Stone, D.S., 1985, Geologic interpretation of seismic profiles, Bighorn Basin, Wyoming, part II - West flank, in Gries, R.R., and Dyer, R.C., eds., Seismic exploration of the Rocky Mountain region: Rocky Mountain Association of Geologists and Denver Geophysical Society, p. 175-187.

Summer, N.S., and Verosub, K.L., 1992, Diagenesis and organic maturation of sedimentary rocks under volcanic strata, Oregon: American Association of Petroleum Geologists Bulletin, v. 76, p. 1190-1199.

Sundell, K.A., 1983, Volcanic stratigraphy, timing, and petroleum exploration in southeastern Absaroka Range. Bighorn Basin, Wyoming [abs]: American Association of Petroleum Geologists Bulletin, v. 67, p. 1357-1358.

Sundell, K.A., 1990, Sedimentation and tectonics of the Absaroka Basin of northwestern Wyoming: Wyoming Geological Association, 41 st Annual Field Conference, p. 105-122. 
Tennyson, M.E., 1995, Eastern Oregon - Washington Province (005), in Gautier, D.L., Dolton, G.L., Takahashi, K.I., and Varnes, K.L., eds., 1995 National Assessment of United States oil and gas resources -- Results, methodology, and supporting data: U.S. Geological Survey Digital Data Series DDS-30 [CD-ROM].

Thomas, L.E., 1965, Sedimentation and structural development of Bighorn Basin: American Association of Petroleum Geologists Bulletin, v. 49, p. 1867-1877.

U.S. Geological Survey National Oil and Gas Resource Assessment Team, 1995, 1995 National Assessment of United States oil and gas resources: U.S. Geological Survey Circular $1118,20 \mathrm{p}$.

Warner, M.M., 1977, The Cenozoic of the Snake River Plain of Idaho, in Heisey, E.L., and others, eds., Rocky Mountain thrust belt geology and resources: Wyoming Geological Association, 29th Annual Field Conference, p. 313-326.

Warner, M.M., 1980, S. Idaho, N. Nevada, southeastern Oregon -- Prime exploration target: Oil and Gas Journal, May 5, p. 325-341.

Withers, R., Eggers, D., Fox, T., and Crebs, T., 1994, A case study of integrated hydrocarbon exploration through basalt: Geophysics, v. 59, p. 1666-1679.

Woods, S.H., 1994, Seismic expression and geological significance of a lacustrine delta in Neogene deposits of the western Snake River Plain, Idaho: American Association of Petroleum Geologists Bulletin, v. 78, p. 102-121. 
Table 1. Gas plays of the USGS 1995 National Assessment (Gautier and others, 1995) that underlie regionally extensive surface volcanics. [A hypothetical play has no discovered accumulations of 6 bcfg or larger. Play probability is an estimate of the chance that at least one accumulation of 6 bcfg or larger exists in the play. $F_{95}$ represents a 19 in 20 chance and $F_{5}$ a 1 in 20 chance of at least the amount of gas tabulated below. bcfg, billion cubic feet of gas.I

\begin{tabular}{llll}
\hline PLAY NUMBER AND NAME; & PLAY STATUS & DEPTH (ft): & UNDISCOVERED, TECHNICALLY \\
PROVINCE NUMBER AND NAME; & AND & min.; med- & RECOVERABLE GAS (bcfg): \\
PROVINCE GEOLOGIST & (PROBABILITY) & ian; max. & F95; mean; $F_{5}$
\end{tabular}

501 Northwestern Columbia Plateau Gas;

5 Eastern Oregon-Washington; M.E. Tennyson

502 Central and NE Oregon Paleogene Gas;

5 Eastern Oregon-Washington; M.E. Tennyson

503 Columbia Basin - Basin-Centered Gas; [continuous (unconventional) play]

5 Eastern Oregon-Washington; B.E. Law

1701 Miocene Lacustrine (Lake Bruneau);

17 Idaho-Snake River Downwarp; J.A. Peterson

1702 Pliocene Lacustrine (Lake Idaho);

17 Idaho-Snake River Downwarp; J.A. Peterson

1703 Pre-Miocene;

17 Idaho-Snake River Downwarp; J.A. Peterson

1704 Older Tertiary;

17 Idaho-Snake River Downwarp; J.A. Peterson

3405 Sub-Absaroka;

34 Big Horn Basin; J.E. Fox and G.L. Dolton

$\begin{array}{lrr}\text { hypothetical } & 500 ; & 0 ; \\ \text { (prob.=0.60) } & 8,000 ; & 235 ; \\ & 15,000 & 1,120 \\ & & \\ \text { hypothetical } & 500 ; & 78 ; \\ \text { (prob.=0.20) } & 3,000 ; & 653 \\ & 12,000 & \\ & & 2,801 ; \\ \text { hypothetical } & 9,500 ; & 12,200 ; \\ \text { (prob.=1.00) } & 13,000 ; & 30,873\end{array}$

hypothetical

3,000;

10,000

20,000

(prob. $=0.19$ )

hypothetical

(prob. $=0.10$ )

(play not quantitatively assessed)

hypothetical

(prob. $=0.07$ )

(play not quantitatively assessed)

hypothetical

(prob. $=0.06$ )

(play not quantitatively assessed)

hypothetical (for gas) $\quad 1,000$;

(prob. not 3,000;

estimated) (play not quantitatively assessed for gas) 


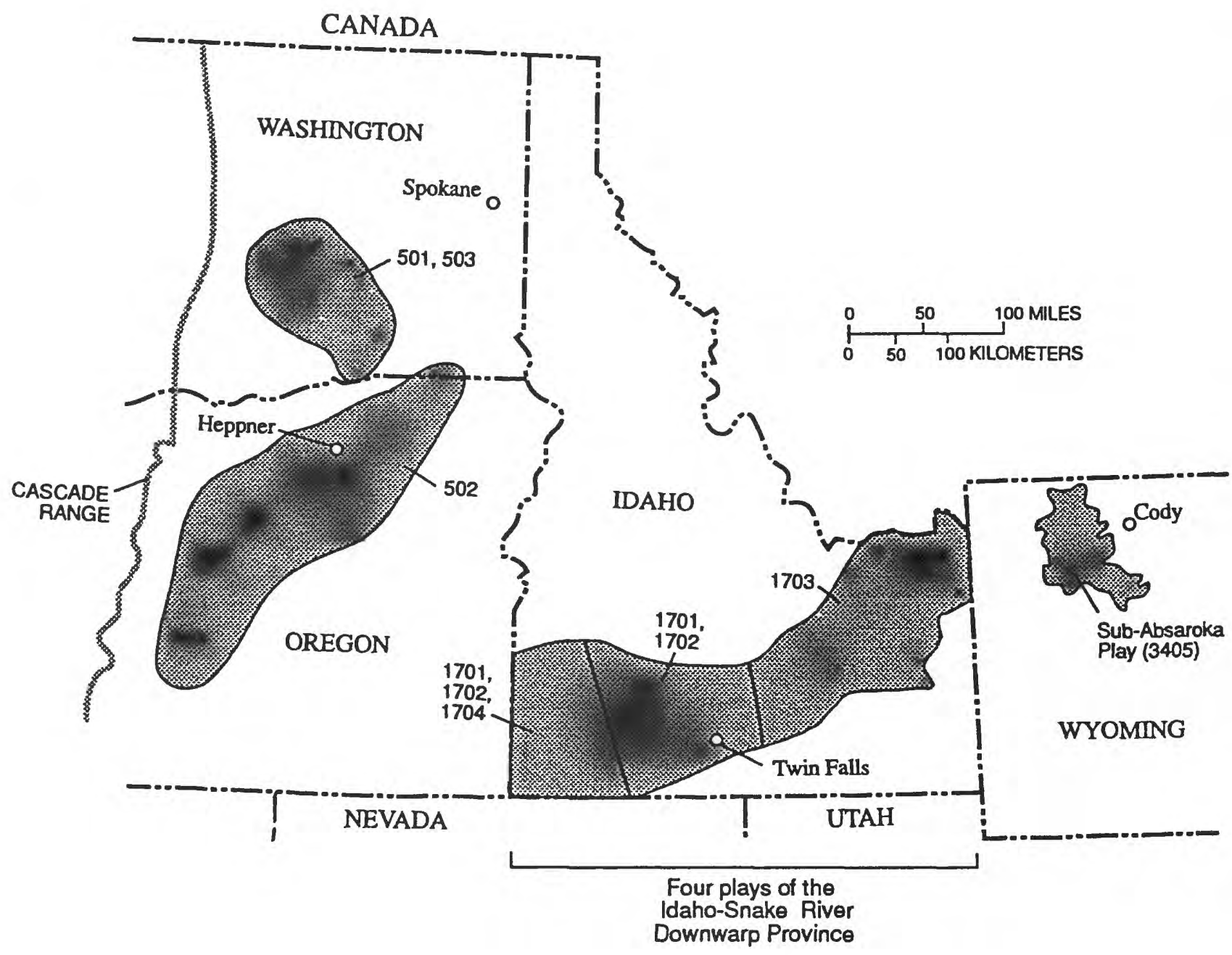

Figure 1. Index map showing the eight plays described in this report. Plays 501, 502, and 503 underlie Columbia River basalts. Plays 1701, 1702, 1703, and 1704 underlie Snake River basalts. Play 3405 underlies Absaroka volcanics. Additional information for each play is given in Table 1. 